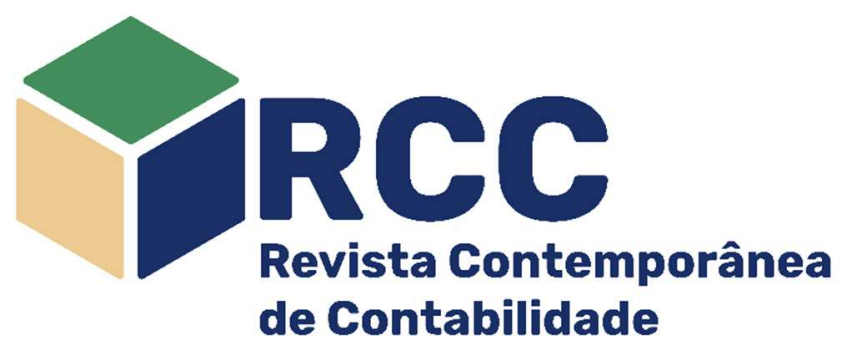

\title{
Directives for public entities' popular financial reporting
}

\author{
Diretrizes para relatórios financeiros populares de entidades públicas \\ Directrices para informes financieros populares de las entidades públicas
}

Fabiana Vale de Sousa Prudente Martins Graduada em Ciências Contábeis pelo Departamento de Ciências Contábeis e Atuariais (UnB), Brasília/DF, Brasil fabianavaledesousa@gmail.com https://orcid.org/0000-0002-2482-2848 (])
Diana Vaz de Lima* Doutora em Ciências Contábeis (UnB/UFPB/UFRN) Pós-Doutorado em Contabilidade e Controladoria pela FEARP (USP) Professora do Departamento de Ciências Contábeis e Atuariais e do Programa de Mestrado Profissional em Administração Pública (UnB), Brasília/DF, Brasi diana lima@unb.b https://orcid.org/0000-0002-4477-445X (1)

Primary contact address for correspondence* Campus Universitário Darcy Ribeiro - Asa Norte, CEP: 70910-900, Brasília/DF, Brasil

\begin{abstract}
This study analyzes different types of Popular Financial Reports (PFR) identifying the main characteristics responsible for achieving effective transparency and improving participative democracy. A model is suggested gathering core information and formatting techniques from national and international governmental experience on publishing reports designed to be intelligible to citizens. The crosschecking of criteria fixed by seven international awards/certificates provides the directives sustaining the proposed model, which also considered the four initiatives adopted in Brazil. When applying the results obtained to the PFR elaboration experiences developed in Brazil, it was found that there is already an evolution when adopting a more attractive look and a wider dissemination, however, the Brazilian reports are still long compared to international ones, and, the content and technical language of official reports still prevail, which makes it difficult for Brazilian citizens who do not have financial or accounting training.
\end{abstract}

Keywords: Popular Financial Reporting; Accountability; Public Sector; Transparency; Participative Democracy

\section{Resumo}

Este estudo analisa diferentes tipos de Relatórios Financeiros Populares (RFP) identificando as principais características responsáveis por alcançar uma transparência efetiva e aprimorar a democracia participativa. É sugerido um modelo que reúna informações essenciais e técnicas de formatação da experiência governamental nacional e internacional na publicação de relatórios concebidos para serem inteligíveis aos cidadãos. O cruzamento de critérios fixados por sete prêmios / certificados internacionais fornece as diretrizes que sustentam o modelo proposto, que considerou também as quatro iniciativas adotadas no Brasil. Ao aplicar os resultados obtidos às experiências de elaboração de RFP desenvolvidas no Brasil, constatou-se que já existe uma evolução na adoção de um olhar mais atraente e de maior divulgação, porém, os relatórios brasileiros ainda são longos se comparados aos internacionais, e, o conteúdo e a linguagem técnica dos relatórios oficiais ainda prevalecem, o que dificulta a compreensão dos brasileiros que não possuem formação financeira ou contábil.

Palavras-chave: Relatórios Financeiros Populares; Prestação de contas; Setor público; Transparência; Democracia Participativa

\section{Resumen}

Este estudio analiza diferentes tipos de Informes Financieros Populares (IFP), identificando las principales características responsables de lograr una transparencia efectiva y promover la democracia participativa. Se sugiere un modelo que recopile información esencial y técnicas de capacitación de la experiencia de los 
gobiernos nacionales e internacionales en la publicación de informes diseñados para para ser inteligibles para los ciudadanos. El cotejo de criterios fijados de siete premios / certificados internacionales proporciona las directrices que sustentan el modelo propuesto, que también consideró cuatro iniciativas adoptadas en Brasil. Al aplicar los resultados obtenidos a las experiencias de elaboración de IFP desarrolladas en Brasil, se encontró que ya existe una evolución al adoptar una mirada más atractiva y una difusión más amplia, sin embargo, los informes brasileños aún son largos en comparación con los internacionales, y el contenido y el lenguaje técnico de los informes oficiales aún prevalecen, lo que dificulta a los ciudadanos brasileños que no tienen formación financiera o contable.

Palabras clave: Informes Financieros Populares; Rendición de Cuentas; Sector Público; Transparencia; Democracia participativa

\section{Introduction}

Transparency in government operations is considered an essential precondition for macroeconomic sustainability, good governance, and overall fiscal rectitude, and popular financial reports (PFR) can contribute in this direction, mainly by providing financial information to a non-technical, citizen audience (Kopits \& Craig, 1998; Jordan et al., 2017). According to Yusuf et al. (2013), citizens have been demanding more public accountability of their governments and governmental programs as "there is a decreasing citizen trust in government and increasing citizen dissatisfaction with government performance." (p.2).

As governments have grown in size and complexity, citizens increasingly view government as inefficient and wasteful in the delivery of public services. However, following an opposite path from the desired popular participation, accountability has been restricted to monetary values that are difficult to understand, compromising the principles of corporate governance, in particular, the transparency of information (Yusuf et al., 2013).

The need of offering more transparence, contributing to participative democracy, has being already perceived in the academy. Brusca and Montesinos (2006) highlight that financial information may reflect the results of public policies and, consequently, may serv as communication instruments revealing economic effects resulting from administrative strategies. They sustain the adoption of more popular reports making the governmental accounting understandable to non-specialists. Since 2010, IPSAS Conceptual Framework has identified citizens as the main users of PFR (Biancone et al., 2020).

In practice, however, many financial reports published by public entities are uneasy to read, requiring specific accounting knowledge, in a way that information is being more hidden than revealed (Manes-Rossi, 2019). In this context, the discussion about governments making information available in an accessible language comes to light. In the case of the PRF, consists of an innovative reporting technique that can facilitate the provision of information serving as the foundation for developing a cadre of informed citizens who can participate in the budgeting/fiscal policy process more effectively (Jordan et al., 2016). "PFR is a general term describing the separate reporting of financial and performance information to a citizen audience in a manner which is more understandable by the public" (Yusuf et al., 2013, p. 2). PFRs are targeted at those stakeholders who have no experience in public finance, but who need or want a less detailed view of government financial activities (Clay \& Olson, 2008; Yusuf \& Jordan, 2012; Biancone et al., 2019).

There can be seen initiatives all over the world, but the main PFR precursors are the United States and Canada. In 2016, Turin became the first European City to publish financial statements prepared under PFR Principles (Biancone, Secinaro \& Brescia, 2016b). Despite its relevance, the theme has been centered in few researchers (Yusuf, Jordan, Cohen, Karatzimas, Biancone, Secinaro, Brescia) and has focused on the American and Canadian experiences.

The goal of this paper is to discuss the preparation and dissemination of PFR evaluating criteria fixed by international certificates and awards related to the theme and providing a conceptual model to be used as guidance for Brazilian public sector entities. The research method consisted of a comprehensive bibliographic review over existing models of PFRs, in the identification of core directives for building a model simple enough to be adopted by different kinds of governmental entities and in the critical analysis of four initiatives adopted in Brazil, aiming at is improvement based on the experience obtained.

This paper was structured in six sections. Following Section 1 introduction, Section 2 discuss the users of accounting information and the concepts characterizing a PFR. Section 3 details the methodology leading to the proposed model. The Section 4 provides the insight extracted from the international experience shaping the conceptual model, and in Section 5 it is presented a critical analysis of four initiatives adopted in Brazil. Finally, in Section 6, the conclusion emphasizes the utility of the proposed model, followed by the references used in the Study. 


\section{Literature Review}

\subsection{Users of the governmental accounting information}

According to the Conceptual Framework by IPSASB (2014), the primary goal of most public sector entities is to deliver services to the public, rather than to make profits and generate a return on equity to investors. These entities are accountable for their management and use of resources to those that provide them with resources, and to those that depend on them to use the resources to deliver necessary services. Also, the objectives of financial reporting by public sector entities are to provide information that is useful to users of General Purpose Financial Reports (GPFR) for accountability and decision-making purposes.

In reality, considering that the recipients of public information are, in general, all the stakeholders and the users of the balance sheet (Biancone, Secinaro \& Brescia, 2016a), not only there is a decreasing citizen trust in governments, but there is also an information gap between citizens and their governments when it comes to government finances (Jordan et al., 2016). According to Yusuf et al. (2013), citizens have been demanding more public accountability of their governments and governmental programs, particularly regarding the stewardship of public resources. Therefore, Public Financial Reports have emerged to deal with this growing concern and lack of confidence in how federal funds are managed and used.

In 2017 the Organization for Economic Co-operation and Development (OECD) published the study called "Government at a Glance" which delivers benchmarked public service performance data, providing a vision on the trends shaping public performance measurement across the OECD and beyond. Among the aspects seen, the measurement of trust in governments revealed a strong correlation with citizens' perception about governor's leadership and susceptibility to corruption. This data reaffirms that there is, indeed, decreasing citizen trust in most governments (OCDE, 2017).

As reported by Sharp et al. (1998), citizens are interested in three questions when it comes to analyzing a financial report: How did the last year turn out? What's new? And also, what is likely to happen in the future? Perhaps most critical than providing citizens with the information they desire is effectively disseminating public financial performance, that is why technical information needs to be synthesized into a more approachable summary (Jordan et al., 2016).

According to Irvin and Stansbury (2004), there are many advantages, but there are also some disadvantages regarding citizen participation in government decision making, such as the difficulty of diffusing citizen goodwill, persistent selfishness, and the cost to the government. Citizens need to be educated and informed before they can engage in decision making and governance effectively, and the reality is that citizens often lack access to the necessary background (Jordan et al., 2016).

In order to answer popular transparency and accountability requests, the PFR has been used in United States capitals and in other countries as a "translation" tool (Biancone et al., 2016b). It is noticed that engaging citizens and incorporating public participation into the decision-making process of determining solutions to the fiscal crises could potentially increase citizen support for the different paths and alleviate public concerns about government waste (Jordan et al., 2016).

\subsection{Concepts and characteristics of PFRs}

Some countries around the world such as the United States, Canada, and even Brazil are encouraged to produce more comprehensive and citizen-friendly reports concerning its financial condition. The United States, for example, has the Comprehensive Annual Financial Report, also known as CAFR, which is a throughout and detailed presentation of what is the state's financial condition (Office of Financial Management of Washington). The CAFR is regulated by the Governmental Accounting Standards Board (GASB). GASB was established in 1984 as the independent, private-sector organization that sets accounting and financial reporting standards for U.S state and local governments that follow Generally Accepted Accounting Principles (GAAP) (Governmental Accounting Standards Board).

Although a CAFR is supposed to be comprehensive, as the name says, they may be overwhelming and unreadable (Sharp et al., 1998). A financial report needs for the information to be readily available and understandable (Yusuf et al., 2013). Therefore, some organizations started to encourage the making of alternative reports such as the PFR and Citizen-centric Reports (CCR) to suppress the need for a more citizenfriendly report. According to Lee (2006) and Cabral and Aquino (2020), the initiative for this new type of report came from the GASB and the Association of Government Financial Directors (GFOA), both American entities, and the name PRF would have come with the publication of WhitePapers (Carpenter \& Sharp, 1992) and the disclosure of an award program called Popular Annual Financial Report (PARF) (Allison, 1995; Cabral \& Aquino, 2020).

Yusuf et al. (2013), also stated that "PFRs have emerged in response to concerns that traditional government financial reports, while accurate and detailed, fail to provide the public with an overall understanding of the governments' uses of public funds" (p.96). Table 1 summarizes how the different authors describes a PFR. Overall, it is made clear that the PFR focus on general public's understanding, readability and usefulness. 
Table 1:

Definitions of a PFR by Different Authors

\begin{tabular}{|c|c|}
\hline PFR's definitions & Authors/Year \\
\hline $\begin{array}{l}\text { Popular reporting should produce a brief and easy readable document, inclusive of financial } \\
\text { reports addressed to citizens' targets. Moreover, it could be subjected to a complete and } \\
\text { easy-going availability of other potential users such as politicians, public sector employees, } \\
\text { the media, community groups, etc }\end{array}$ & (GASB, 1992) \\
\hline $\begin{array}{l}\text { PFRs are defined as financial reports targeted at public stakeholders (e.g., citizens, } \\
\text { businesses and community groups) who lack a background in public finance but who need } \\
\text { or desire a less detailed overview of the government's financial activities. The PFR's purpose } \\
\text { is to facilitate public stakeholders' understanding of their government's financial activities. }\end{array}$ & $\begin{array}{l}\text { (Yusuf \& Jordan, } \\
\text { 2012) }\end{array}$ \\
\hline $\begin{array}{l}\text {...financial reports which state and local governments distribute to citizens and other } \\
\text { interested parties who may lack a background regarding government budgeting, accounting } \\
\text { and financial reporting but who need or desire an overview of the government's financial } \\
\text { activities and condition. }\end{array}$ & (Yusuf et al., 2013) \\
\hline $\begin{array}{l}\text { Popular reporting refers to the preparation of concise, easily read, comprehensive and user- } \\
\text { friendly financial reports mainly focussing on citizens' needs }\end{array}$ & $\begin{array}{l}\text { (Cohen \& Karatzimas, } \\
\text { 2015) }\end{array}$ \\
\hline $\begin{array}{l}\text { PFR, as a reporting mechanism targeted at the general public, can be an important } \\
\text { government reporting mechanism for improving transparency of government budgetary and } \\
\text { financial information, contributing to effective public participation through ensuring an } \\
\text { informed citizenry, and enhancing government's accountability to citizens }\end{array}$ & (Yusuf \& Jordan, 2015) \\
\hline $\begin{array}{l}\text { The popular report is an accounting tool that has potential for development and } \\
\text { implementation. }\end{array}$ & $\begin{array}{l}\text { (Biancone et al., } \\
\text { 2016a) }\end{array}$ \\
\hline $\begin{array}{l}\text { It is a reporting innovation that can facilitate provision of information that serves as the } \\
\text { foundation for developing a cadre of informed citizens who can then more effectively } \\
\text { participate in the budgeting/fiscal policy process }\end{array}$ & (Jordan et al., 2016) \\
\hline $\begin{array}{l}\text { An instrument of consolidated economic property and financial cost reporting. It completes } \\
\text { financial, economic, patrimonial, quantitative and qualitative information of the consolidated } \\
\text { group with a simple language, comprehensible to unauthorized personnel and all the citizens }\end{array}$ & $\begin{array}{l}\text { (Biancone; Secinaro \& } \\
\text { Brescia, 2017) }\end{array}$ \\
\hline $\begin{array}{l}\text { Designed to be useful to constituents by providing less detail and more of an overview, of the } \\
\text { government's financial activities and condition. }\end{array}$ & $\begin{array}{l}\text { (Groff; Pitman \& Tervo, } \\
\text { 2017) }\end{array}$ \\
\hline
\end{tabular}

Source: GASB (1992); Yusuf and Jordan (2012); Yusuf et al. (2013); Cohen and Karatzimas (2015); Yusuf and Jordan (2015); Biancone et al. (2016a); Biancone et al. (2017); Jordan et al. (2016); Groff et al. (2017).

In the United States, the PFR receives its most specific guidance from the Government Finance Officers Administration (GFOA). It is also encouraged by other organizations like Association of Government Accountants (AGA) and also by the GASB (Yusuf, Jordan, Neill \& Hackbart, 2013). GFOA represents public finance officials throughout the United States and Canada. The organization provides best practice guidance, consulting, and training opportunities for those in the profession. It also offers a different approach to the financial statement in the general accepted accounting principles (GAAP), which is the common set of accounting principles, standards, and procedures used by companies to compile their financial statement (Biancone et al., 2016b).

According to Cabral and Aquino (2020), ideally the PFRs have typical characteristics. Its content should be summarized, using official reports in simple language as a reference, and the document is expected to be attractive and didactic, with information of interest to users disseminated frequently and elaborated from a reliable source (Sharp et al., 1998; Hermann, 2011; Cohen \& Karatzimas, 2015; Cohen; Mamakou \& Karatzimas, 2017; Oliveira, 2013; Cabral \& Aquino, 2020). For Biancone et al. (2016a) and Cabral and Aquino (2020), PFR is generally seen as a translation of traditional reports.

According to Yusuf et al. (2013), PFRs can come in a variety of forms, such as popular annual financial reports (PAFR), citizen's guide to the budget, reports of service efforts and accomplishments, corporate-style annual reports, and state-of-the-government reports. Citizen input on these key issues is an important precursor for defining the effectiveness of popular reporting as a tool for transparency and accountability (Yusuf \& Jordan, 2012). Choosing the appropriate report format, depth of coverage, and complexity of presentation, preparers need to consider citizens' education, interests, and involvement in local government (Sharp et al., 1998). Hermann (2011) made an article on ten tips that can help to produce a highly effective popular report (Figure 1). 


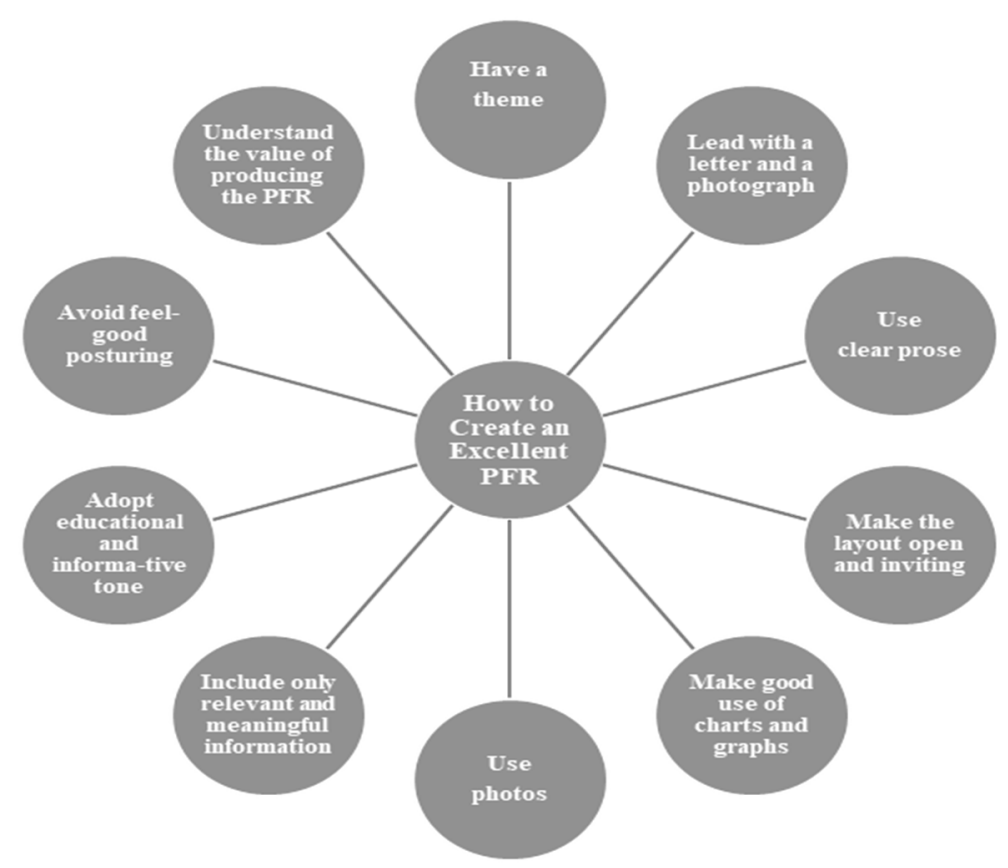

Figure 1 - How to Create a PFR

Source: Adapted from Hermann (2011)

Indeed, no comprehensive playbook provides all the guidance necessary to produce an effective report. Sometimes a lousy report is easier to recognize than a good one (Hermann, 2011). It can be noticed that the most recurrent PFR's characteristics are: an inviting and understandable layout; the right report format; and a heavy focus on effective dissemination.

\subsection{Integrated Report Reporting}

The Integrated Popular Reporting can be described as a concise communication about how an organization's strategy, governance, performance, and prospects, in the context of its external environment, lead to the creation of value over the short, medium, and long-term (Biancone et al., 2016a). It is an example of recent formats emerged to achieve social expectations about PFR (Figure 2).

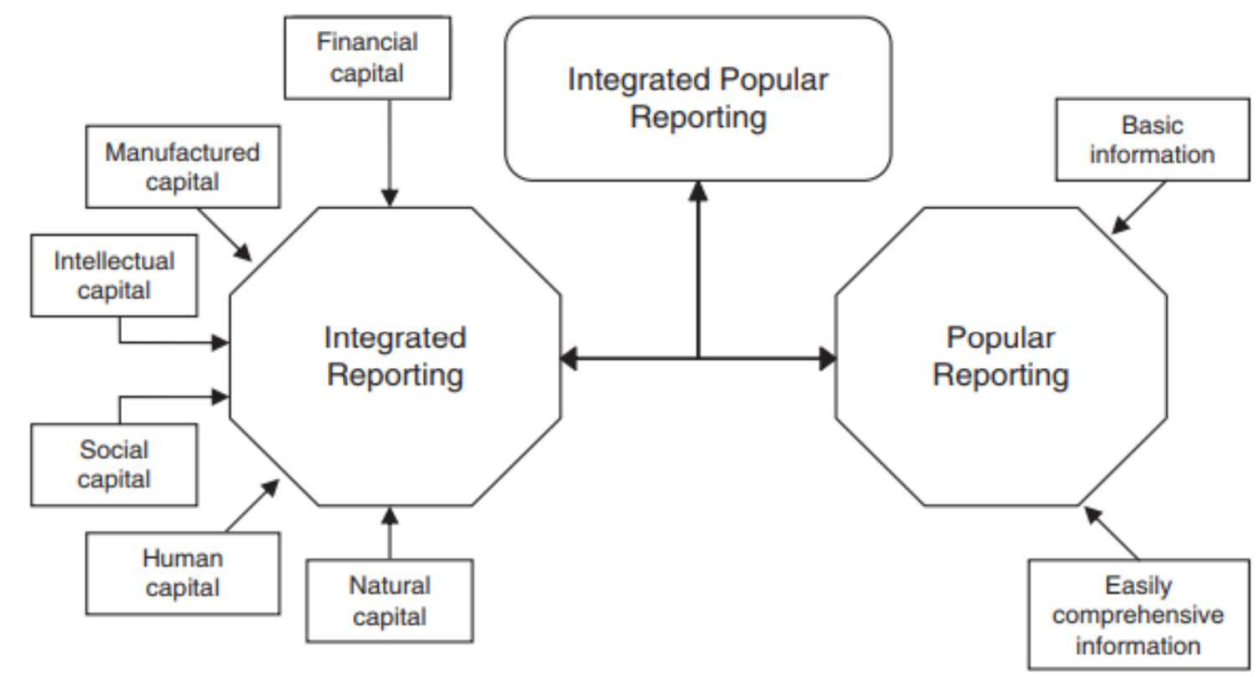

Figure 2 - Integrated Popular Reporting

Source: Cohen and Karatzimas (2015, p. 456)

This report was created to combine a successful and effective report with an innovative report. Instead of compromising between the provision of an easily understandable report with just financial information or a complex extensive non-financial information report, the IPR comes with a proposal of being somewhere in the middle of this "pole of complexity" (Cohen \& Karatzimas, 2015). The Figure 3 synthesizes the process of drafting a popular consolidated report. 


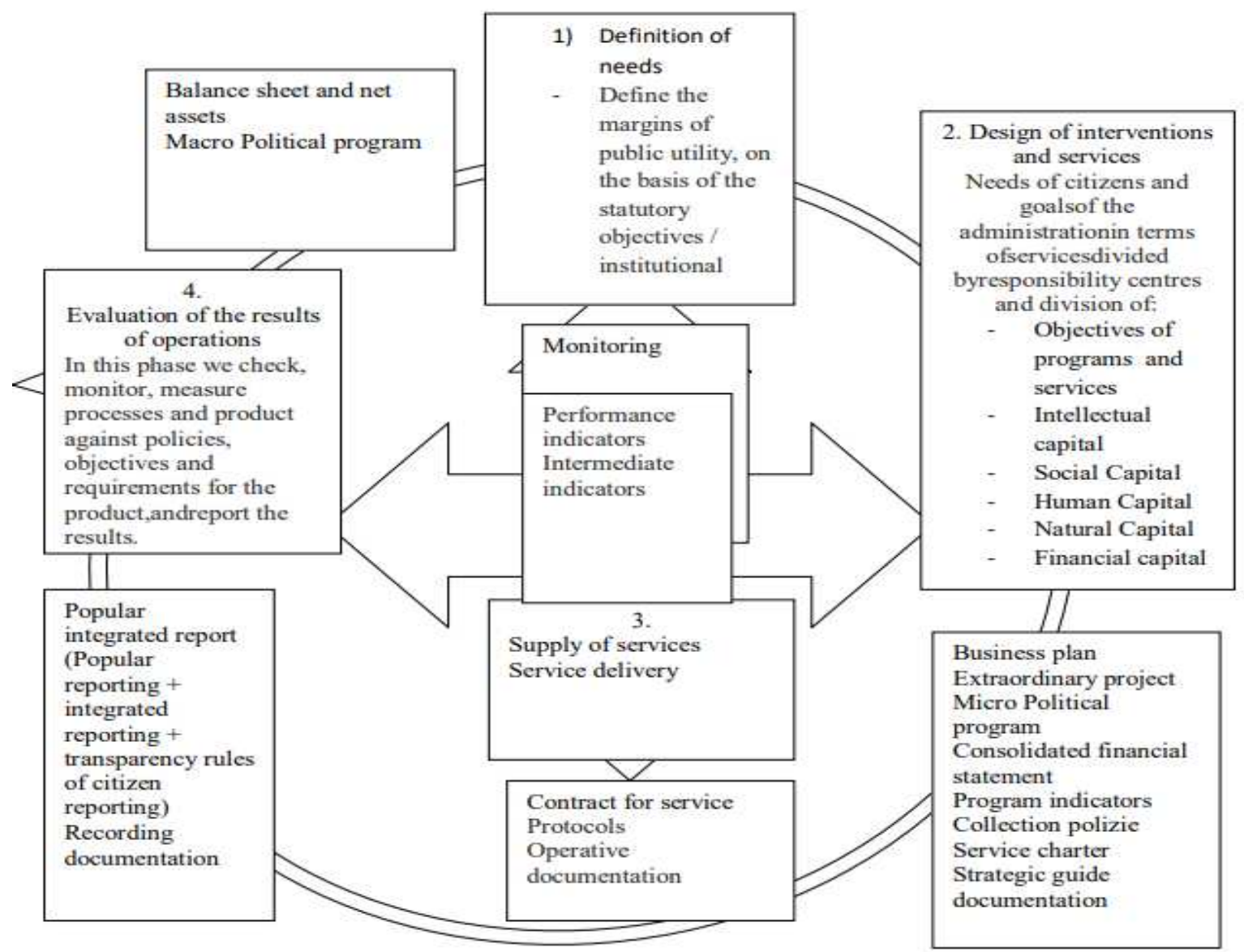

Figure 3 - The Process of drafting a Popular Consolidated Report

Source: Biancone et al. (2016a, p. 121)

Other studies identify a tool of transparency on IPR reporting that combines the most material elements of information currently included in separate reporting strands (financial, management commentary, governance and remuneration, and sustainability) into a coherent whole (Biancone et al., 2016a). Based on the principle that an IPR must address the exact communication required by both prepares and receivers, safeguarding the necessary agility in reporting, there could not be a single and restrictive IPR template. Although guidelines on its development should be provided, this should only take place in a spirit of consultation (Cohen \& Karatzimas, 2015).

In Brazil, the Federal Court of Accounts (TCU), a body that is part of the list of superior supervisory entities worldwide, approved in 2020 a package of rules aimed at rationalizing and simplifying procedures, including TCU Normative Instruction no 84/2020 and Normative Decisions No. 187/2020 and 188/2020. Among others, these regulations establish that the accountability management report of the Brazilian central government must be presented in the form of an integrated report, with a clear and concise view of the facts to be reported.

\section{Research Methodology}

For establishing a conceptual model of PFR, the ten tips for producing a highly effective popular report, presented by Hermann (2011), were combined with the most recurrent characteristics identified on existing models pointed by different authors (GASB, 1992; Yusuf \& Jordan, 2012; Yusuf et al., 2013; Cohen \& Karatzimas, 2015; Yusuf \& Jordan, 2015; Biancone et al., 2016a; Biancone et al., 2017; Jordan; Yusuf; Mayer \& Mahar, 2016; Groff et al., 2017).

As the intention of the research was exploratory in nature, in order to obtain knowledge and understanding on the topic for its discussion in the Brazilian public sector environment, non-probabilistic sampling (convenience sample) was used. In this way, seven selected international awards/certificates related to the theme were found through a series of on-line searches from August to October 2018. The relevant items identified were: The Popular Annual Financial Report Award Program; The Public Finance Awards; The Canadian Award for Financial Reporting Program; the Certificate of Excellence in Financial Reporting; The Certificate of Excellence in Citizen-centric Reporting. The Open Government Partnership; and the Certificate of Achievement for Excellence in Financial Reporting Program.

Information obtained at the official websites of each organization responsible for each award/certificate indicated in Table 2 revealed the eligibility criteria as presented in Table 3 . These criteria were combined to 
the characteristics previously explored leading to the development of the proposed conceptual model. Based on these findings, a critical analysis of four initiatives adopted in Brazil was carried out.

\section{Learning with the International Experience}

\subsection{International awards}

According to Biancone et al. (2020), PFRs have gained increasing attention from academics, managers and politicians, being promoted by several professional associations, including awards. There are initiatives to spread more comprehensive information to the average citizen since 1945. Thus, celebrating such actions, there are awards and programs rewarding the precursors of those ideas. The United States and Canada deserves to be highlighted as the pioneers on the subject, as can be noticed in Table 2. However, recent efforts became public in Europe, and also, some worldwide attempts start to move the academy towards the subject.

Each selected award/certificate is described in table 2 focusing the objectives established by the organization. It shall be noticed that supporting evidence may include: reports demonstrating success, internal or external testimonials, press cuttings, audited accounts or annual reports.

Table 2:

Awards Summary

\begin{tabular}{|c|c|c|}
\hline Certificate/Award & $\begin{array}{c}\text { Country and } \\
\text { Year }\end{array}$ & Concept \\
\hline $\begin{array}{l}\text { Certificate of } \\
\text { Achievement for } \\
\text { Excellence in Financial } \\
\text { Reporting Program }\end{array}$ & $\begin{array}{c}\text { USA/CA } \\
1945\end{array}$ & $\begin{array}{l}\text { "encourage and assist state and local governments to go beyond the } \\
\text { minimum requirements of generally accepted accounting principles to } \\
\text { prepare comprehensive annual financial reports that evidence the spirit } \\
\text { of transparency and full disclosure and then to recognize individual } \\
\text { governments that succeed in achieving that goal" }\end{array}$ \\
\hline $\begin{array}{l}\text { Certificate of } \\
\text { Excellence in Financial } \\
\text { Reporting (COE) }\end{array}$ & $\begin{array}{l}\text { USA } \\
1973\end{array}$ & $\begin{array}{l}\text { "(COE) has honored school districts for their high quality } \\
\text { Comprehensive Annual Financial Reports (CAFRs)" }\end{array}$ \\
\hline $\begin{array}{l}\text { Canadian Award for } \\
\text { Financial Reporting } \\
\text { Program }\end{array}$ & $\begin{array}{c}\text { Canada } \\
1986\end{array}$ & $\begin{array}{l}\text { "encourage and assist Canadian local governments to go beyond } \\
\text { the minimum requirements of generally accepted accounting } \\
\text { principles, as set by the Public Sector Accounting Board of the } \\
\text { Canadian Institute of Chartered Accountants, to prepare } \\
\text { comprehensive annual financial reports that evidence the spirit of } \\
\text { transparency and full disclosure and then to recognize individual } \\
\text { governments that succeed in achieving that goal" }\end{array}$ \\
\hline PAFR Awards Program & $\begin{array}{l}\text { USA/CA } \\
1991\end{array}$ & $\begin{array}{l}\text { "encourage and assist state and local governments to extract } \\
\text { information from their comprehensive annual financial report to produce } \\
\text { high quality popular annual financial reports specifically designed to be } \\
\text { readily accessible and easily understandable to the general public and } \\
\text { other interested parties without a background in public finance and then } \\
\text { to recognize individual governments that are successful in achieving } \\
\text { that goal" }\end{array}$ \\
\hline $\begin{array}{l}\text { Certificate of } \\
\text { excellence in Citizen- } \\
\text { Centric Reports }\end{array}$ & $\begin{array}{l}\text { Worldwide } \\
2007\end{array}$ & $\begin{array}{l}\text { "AGA offers a Certificate of Excellence in Citizen-Centric Reporting for } \\
\text { entities that prepare and distribute a high-quality Citizen-Centric Report } \\
\text { (CCR). To be eligible for the certificate, governments must incorporate } \\
\text { into their report the program's high standards of content, visual appeal, } \\
\text { readability, distribution and timeliness in reporting as outlined below in } \\
\text { the Judging Guidelines." }\end{array}$ \\
\hline $\begin{array}{l}\text { Open Government } \\
\text { Partnership }\end{array}$ & $\begin{array}{l}\text { Worldwide } \\
2011\end{array}$ & $\begin{array}{l}\text { "Open Government Partnership brings together government reformers } \\
\text { and civil society leaders to create action plans that make governments } \\
\text { more inclusive, responsive and accountable" }\end{array}$ \\
\hline Public Finance Awards & $\begin{array}{l}\text { UK } \\
2016\end{array}$ & $\begin{array}{l}\text { "The Awards will recognize the people, products and services that } \\
\text { demonstrate excellence and originality within public finance (...). } \\
\text { Judged by a panel of distinguished industry leaders." }\end{array}$ \\
\hline
\end{tabular}

Source: Certificate of Excellence in Financial Reporting from https://asbointl.org/awards-career-development/certificate-ofexcellence-in-financial-reporting; Citizen-Centric Reporting from https://www.agacgfm.org/StandardsGuidance/CCR.aspx; Government Finance Officers Association. (n.d.). Certificate of Achievement for Excellence in Financial Reporting (CAFR Program) from http://www.gfoa.org/certificate-achievement-excellence-financial-reporting-cafrprogram; Popular Annual Financial Reporting Award Program from http://www.gfoa.org/pafr; Brazil. from https://www.opengovpartnership.org/countries/brazil; Achievement in Financial Reporting \& Accountability. from https://www.publicfinanceawards.co.uk/categories/ 
One aspect to be highlighted is that there is no single model for preparing the PFR: while the AngloSaxon model should not exceed seven pages, in the Italian context a more discursive form of the document is needed (Biancone et al., 2019). When analyzing the content of the PFRs of 193 municipalities in an award program in 2017, the researchers identified 48 characteristics divided into seven groups: (i) number of pages or length; (ii) understanding; (iii) focus; (iv) capital structures; (v) finance; (vi) appearance and (vii) access. According to them, most of the PFRs in the analyzed sample did not respect or implement the characteristics suggested by the literature, but the size of the document remains an important feature to be assessed in the construction of the PFRs: $60 \%$ of the reports were between 12 and 32 pages, and the remainder up to 12 pages, so it is unclear, the number of pages to be presented.

\subsection{Conceptual model}

\subsubsection{Synthesis of the Eligibility Requirements}

The awards listed in Table 2 establishes some eligibility requirements as conditions for application. Although these requirements vary according to the award, there are requirements in common, which is the point of interest for a general model. In order to define a conceptual model, recurrent requirements are identified and understood as detailed in Table 3.

Table 3:

Eligibility Requirements of the Awards

\begin{tabular}{|c|c|}
\hline Certificate/Award & Eligibility Requirements \\
\hline \multirow{7}{*}{$\begin{array}{l}\text { Certificate of Achievement } \\
\text { for Excellence in Financial } \\
\text { Reporting Program } \\
\text { (CAFR program) }\end{array}$} & $\begin{array}{l}\text { Type of Report: The report submitted to the program must be the published comprehensive annual } \\
\text { financial report of a state or local governmental entity. }\end{array}$ \\
\hline & $\begin{array}{l}\text { Scope: Must include all funds and component units of the entity, in accordance with generally } \\
\text { accepted accounting principles. }\end{array}$ \\
\hline & $\begin{array}{l}\text { Audit requirements: Must include an independent auditor's report on the fair presentation of the } \\
\text { financial statements. }\end{array}$ \\
\hline & $\begin{array}{l}\text { Responses to prior year comments: If the government participated in the program in the preceding } \\
\text { year, its submission package must include written responses to all of the prior year's comments } \\
\text { and suggestions for improvement. }\end{array}$ \\
\hline & $\begin{array}{l}\text { Demonstration of legal compliance: If the CAFR references a separately issued budgetary report } \\
\text { to demonstrate budgetary compliance at the legal level of control, it must submit one copy of that } \\
\text { report as part of its submission package. }\end{array}$ \\
\hline & $\begin{array}{l}\text { Submission Deadline: All appropriate items must be postmarked or e-mailed to the Government } \\
\text { Finance Officers Association (GFOA) no later than six months after the government's fiscal year } \\
\text { end. }\end{array}$ \\
\hline & $\begin{array}{l}\text { In-house Reviews of Ineligible Reports: Occasionally, a government that submits a CAFR that is } \\
\text { deemed ineligible will desire to have staff perform an in-house only review of their report }\end{array}$ \\
\hline \multirow{6}{*}{$\begin{array}{l}\text { Certificate of Excellence } \\
\text { in Financial Reporting } \\
\text { (COE) }\end{array}$} & Completed COE application \\
\hline & Cover letter: specifying any COE criteria that do not aplli to the school district \\
\hline & $\begin{array}{l}\text { COE checklist: questions about the quality and specifications of various aspects of the report } \\
\text { related to the report cover, title page, table of contents, introduction section, financial section and } \\
\text { lastly the statistical section }\end{array}$ \\
\hline & Reviewer comments from the previous year \\
\hline & The School district's responses to the previous year's comments \\
\hline & Comprehensive Annual Financial Report \\
\hline \multirow{4}{*}{$\begin{array}{l}\text { Canadian Award for } \\
\text { Financial Reporting } \\
\text { Program }\end{array}$} & $\begin{array}{l}\text { The report conforms to generally accepted accounting principles (GAAP) as set by the Public } \\
\text { Sector Accounting Board of the Canadian Institute of Chartered Accountants }\end{array}$ \\
\hline & The report has received an unqualified opinion from the independent auditor. \\
\hline & $\begin{array}{l}\text { Governments that submitted their report to the program the preceding year must provide a formal } \\
\text { written response to the prior year's comments }\end{array}$ \\
\hline & Submissions must be received within six months of the end of the fiscal year. \\
\hline \multirow{4}{*}{$\begin{array}{l}\text { Popular Annual Financial } \\
\text { Reporting Awards } \\
\text { Program }\end{array}$} & The PAFR must clearly advise readers of the availability of the CAFR. \\
\hline & $\begin{array}{l}\text { If the PAFR contains information from only selected funds, or if the PAFR does not include all } \\
\text { component units, that fact must be disclosed }\end{array}$ \\
\hline & $\begin{array}{l}\text { The financial information contained in the PAFR must be derived from the actual GAAP data in the } \\
\text { CAFR. }\end{array}$ \\
\hline & $\begin{array}{l}\text { Some form of appropriate narrative or graphic analysis must be provided to explain items of } \\
\text { potentially significant interest or concern }\end{array}$ \\
\hline \multirow{10}{*}{$\begin{array}{l}\text { Certificate of excellence in } \\
\text { Citizen-Centric Reports }\end{array}$} & How the entity is organized/operates \\
\hline & $\begin{array}{l}\text { Key accomplishments surrounding missions and service, along with selected performance } \\
\text { measures }\end{array}$ \\
\hline & Bar and/or pie charts to display revenues and expenses \\
\hline & Audit Information \\
\hline & Future challenges affecting the entity \\
\hline & Feedback Statements \\
\hline & Report is free of technical accounting language \\
\hline & Report incorporates pictures and other graphics to make it visually appealing \\
\hline & Report has been distributed \\
\hline & Include the CCR logo in the report to promote the program's brand \\
\hline
\end{tabular}




\begin{tabular}{|c|c|}
\hline Certificate/Award & Eligibility Requirements \\
\hline \multirow[t]{2}{*}{$\begin{array}{l}\text { Open Government } \\
\text { Partnership }\end{array}$} & $\begin{array}{l}\text { Must exhibit a demonstrated commitment to open government in four Core Eligibility areas: Fiscal } \\
\text { Transparency, Access to Information, Asset Disclosure, and Citizen Engagement. Countries can } \\
\text { earn a total of } 16 \text { points for their performance in these four metrics, or } 12 \text { points if the country is } \\
\text { not assessed in one of the metrics. Countries that earn } 75 \% \text { of the applicable points (either } 12 \text { out } \\
\text { of } 16 \text { or } 9 \text { out of } 12 \text { ) or more are considered to meet the Core Eligibility criteria. }\end{array}$ \\
\hline & $\begin{array}{l}\text { Must pass the OGP Values Check: countries must score three or higher on at least one of the } \\
\text { following two V-Dem indicators: Measuring the extent to which the government achieves control } \\
\text { over entry and exit by civil society organizations (CSOs) into public life; And measuring the extent } \\
\text { to which the government attempts to repress civil society organizations (CSOs). }\end{array}$ \\
\hline \multirow{4}{*}{$\begin{array}{l}\text { Public Finance Awards } \\
\text { Category: "Achievement } \\
\text { in Financial Reporting and } \\
\text { Accountability" }\end{array}$} & $\begin{array}{l}\text { Demonstrate how they have delivered high quality financial reporting in line with accepted } \\
\text { accounting principles that is accessible and readily understood by the public. }\end{array}$ \\
\hline & $\begin{array}{l}\text { Demonstrate how this contains good quality content that is clear and concise and has had a } \\
\text { measurable impact on the community, making organizational performance more transparent and } \\
\text { accessible to scrutiny. }\end{array}$ \\
\hline & $\begin{array}{l}\text { Reports demonstrating success, internal or external testimonials or press cuttings (supporting } \\
\text { evidence) }\end{array}$ \\
\hline & Audited accounts or annual report (supporting evidence) \\
\hline
\end{tabular}

Source: Certificate of Excellence in Financial Reporting from https://asbointl.org/awards-career-development/certificate-of-excellence-infinancial-reporting; Citizen-Centric Reporting from https://www.agacgfm.org/Standards-Guidance/CCR.aspx; Government Finance Officers Association. (n.d.). Certificate of Achievement for Excellence in Financial Reporting (CAFR Program) from http://www.gfoa.org/certificate-achievement-excellence-financial-reporting-cafr-program; Popular Annual Financial Reporting Award Program from http://www.gfoa.org/pafr; Brazil. from https://www.opengovpartnership.org/countries/brazil; Achievement in Financial Reporting \& Accountability. from https://www.publicfinanceawards.co.uk/categories/

For the purpose of this work, an eligibility requirement was considered recurrent if it appears in three awards or more. Therefore, as shown in Table 2, it can be noticed that:

- Four awards/certificates require compliance with accepted accounting principles. For example, The United States and Canada demand compliance with the Generally Accepted Accounting Principles (GAAP).

- Three awards/certificates request that information must be audited, and in the Public Finance Awards it can be provided as supporting evidence, but it is not mandatory.

- Four awards are explicitly concerned with the report's content when it comes to reaching its goal, requiring, for example, that the information must be accessible; easily understandable; free of accounting language; illustrated and visually appealing; and effectively distributed.

- Four awards require feedback statements or reviewer comments from the previous year (if the government participated in preceding years). It means the award needs to encourage the governments or the users of the report to provide a feedback.

Summarizing, the four most recurrent eligibility requirements were: accordance with accepted accounting principles, audited information, report's content, feedback statements or reviewer comments from the previous year. In the case of Brazil, at least one of the characteristics required by international awards / certificates - Independent Auditors' Report - at first cannot be observed, since the inspection of Brazilian public accounts is done by courts of accounts that, despite being technical and independent bodies are part of the administrative structure of the respective Brazilian federated entities that they supervise.

\subsubsection{Conceptual Model by International Experience}

Based on the discussions presented and based on the guidelines required by international awards / certificates, it is proposed that the conceptual model contains nine characteristics: basic information, easily understandable, audited information, feedback statements, accordance with generally accepted accounting principles, visually appealing, distribution of the report, relevant content and focus on the citizens (Figure 4). 


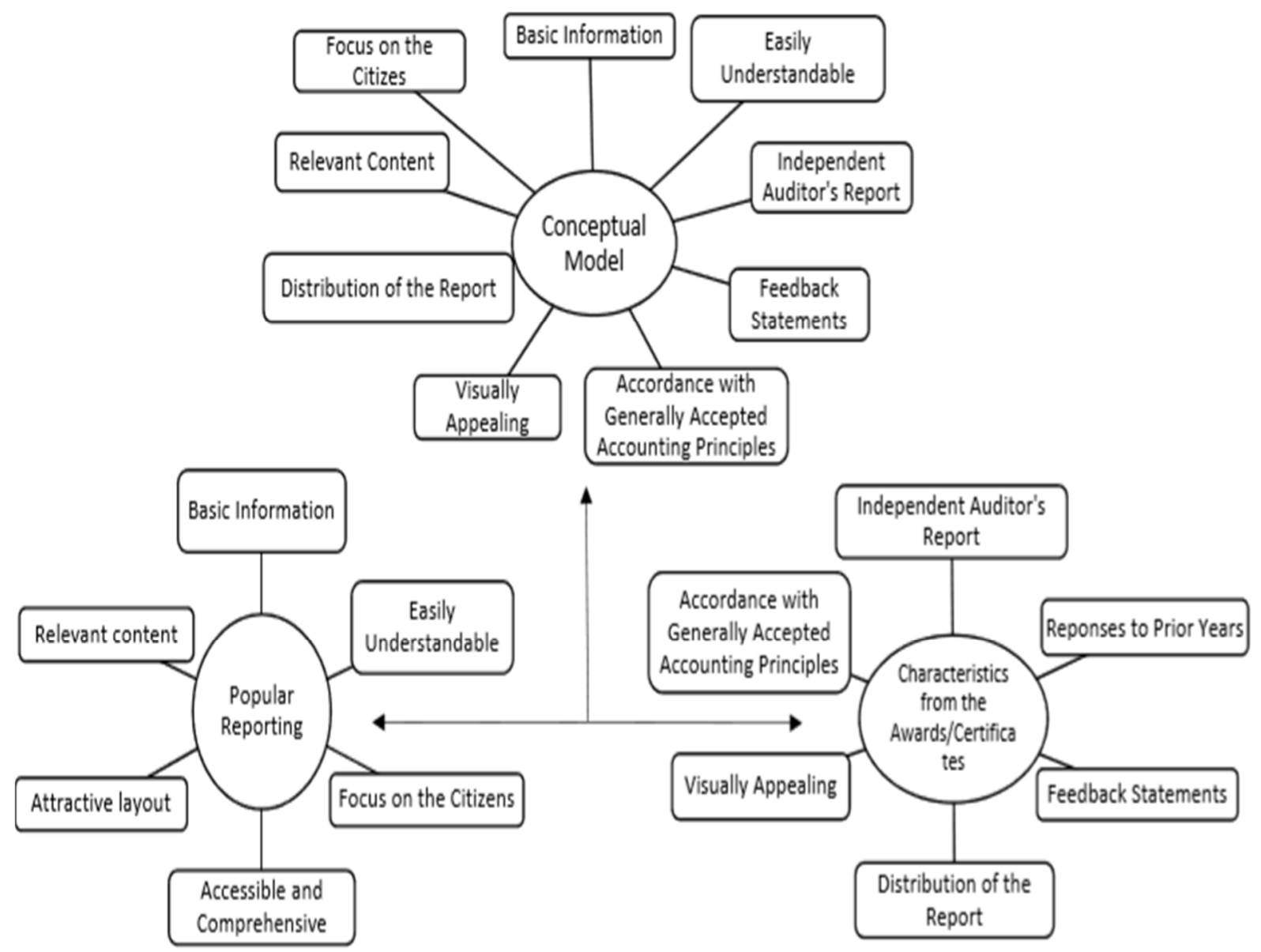

Figure 4 - Conceptual Model

Source: Adapted from Table 1 and Table 3.

When elaborating this conceptual model, it was taken out the characteristic "Responses to Prior Years" because, for the purpose of this study, it does not depend on have being submitted to any award. The characteristics "Attractive Layout" and "Accessible and comprehensive" were also retrieved because they are covered by "Visually Appealing" and "Easily Understandable" respectively. Moving on about the selected characteristics, we present the following clarifications:

a. Basic information: one of the main purposes of a PFR is to provide an information that offers a simplified view of financial statements and, therefore, avoiding detailed analysis or the use of complicated technical terms (Cohen \& Karatzimas, 2015);

b. Easily understandable: it is recommended to avoid jargon and technical language that might not be immediately understandable to those without a financial or accounting background (Hermann, 2011);

c. Focus on the citizens: The measure of real success is whether the citizens get the message and to make that happen, preparers need to give serious attention to the concerns of the citizens and to the message local officials want to deliver (Sharp et al., 1998).

d. Relevant Content: The information presented should be relevant, organized, and presented in a meaningful manner so that citizens can understand how it relates to or impacts them (Jordan et al., 2016).

e. Audited Information: Shows more credibility and contributes to the development of a more reliable report (Biancone et al., 2016a)

f. Feedback Statements: The users of PFR's are usually encouraged to provide a Feedback statement to verify the utility of the report, if it reaches the goal and is able to influence citizens, providing public inputs regarding current and emerging policy issues. (Yusuf et al., 2013).

g. Distribution of the Report: The information needs to be accessible. An appropriate and effective propagation of the report needs to be made so the results can be properly seen (Clay, 2010);

h. Visually Appealing: The report's typography should be easy to read and appealing to the reader, it is recommended the use of graphs, illustrations, different colors and charts to simplify the complexity of the material (Sharp et al., 1998; Clay, 2010; Hermann, 2011; Yusuf \& Jordan, 2015; Jordan et al., 2016);

i. Accordance with Generally Accepted Accounting Principles: The report must respect the generally accepted accounting principles to reinforce its legitimacy (Biancone et al., 2016a) 
Regarding the "easily understandable" characteristic, when it comes to accounting information, one of the paths proposed by Cabral and Aquino (2020) is to replace accounting jargon with more familiar words, accompanied by context or examples that help readers to make sense of the presented contents, admitting eventual losses of details of the information for the benefit of the attractiveness and understanding of the nonspecialists. Another suggestion made by the researchers is that the dissemination of the PFRs accompanied by short videos on social media may have better results, as it combines other language elements better, favoring the understanding of the message.

Adapting to the Brazilian Government, an important aspect to be considered is that Brazil is a code-law country, which means that there is a high degree of detail in the rules to be applied, making official reports have a "plastered" structure. Another issue is that although it is important to explore the understanding of government reports by non-experts - since the use (with greater understanding and engagement) of PFRs would be the reason for all government data transparency and openness initiatives as the solution participatory democracy (Cabral \& Aquino, 2020) - in Brazil the participation of these actors is still not very effective and needs to be better explored (Silva \& Medeiros, 2020).

\section{Critical Analysis of the Brazilian Experience from the International Experience}

Brazil presents some important initiatives on PFR, despite of the maintenance of technical language. Four of them were elected most relevant for analysis: (i) the simplified annual report of the State of Bahia (ii) the integrated management report of the Ministry of Economy; (iii) the Open Government Partnership (OGP) program; and (iv) the Citizen's Accounting Statement (DCC).

\subsection{Simplified Annual Accountability Report for the State of Bahia}

One of the first examples regarding the Brazilian experience is the Simplified Annual Accounts Report of The State of Bahia ("Prestação de contas anual simplificada da Bahia") started in 2015. This report is an instrument of accountability provided by the Bahia's Government including: The Governor accounts, revenues, expenses, and the management strategy applying public resources. The 2018 version of the report, organized in 21 chapters covering 42 pages, brings a more didactic language and focus on the citizens, with a visual programming that stands out for the quality of the illustrations. (Figure 5).

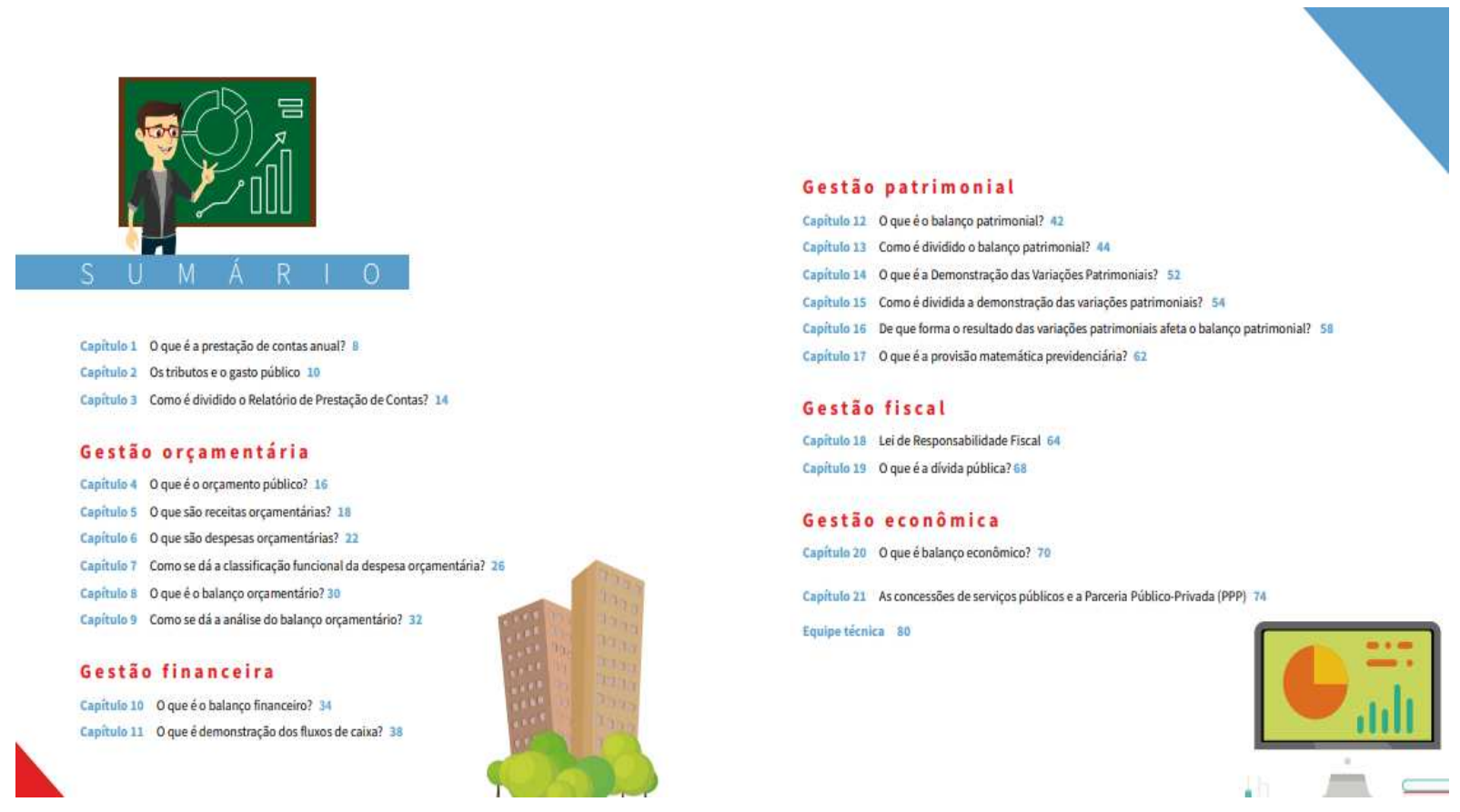

Figure 5 - Simplified Annual Accounting Report - State of Bahia 2018

Source: Secretaria da Fazenda da Bahia (2018)

In light of the characteristics presented in the conceptual model (Figure 4), the Simplified Annual Accounts Report of The State of Bahia already meets some characteristics, such as Visually Appealing (with the use of graphs, illustrations, different colors and charts to simplify the complexity of the material), Distribution of the Report (this report was distributed in its printed version in schools, libraries and public institutions), has Relevant Content and is in Accordance with Generally Accepted Accounting Principles. Despite the attempt of making a more didactic and colorful report, the reality is still a technical document in terms of language. The financial statements are reproduced keeping the same technical language used in official reports, difficult to 
understand for those who do not have a financial or accounting background. Still long, the 2018 version features 42 pages, which can impact printing costs and its distribution. It is an important step to PFR but it still lacks development to reach the intended effects.

\subsection{Integrated Management Report of the Ministry of Economy - Financial Year 2019}

The Integrated Management Report of the Ministry of Economy is a document that enables Brazilian citizens to comprehend how taxpayer's money is spent to deliver economic and fiscal policies which are capable of promoting economic growth and social development. It refers to the rendering of annual accounts to the Federal Audit Court (TCU), in compliance with article 70 of the Federal Constitution of Brazil. The 2019 financial year version was organized into 152 pages, divided into four chapters: (i) ministry governance; (ii) management results; (iii) management compliance and efficiency; and (iv) budgetary, financial and accounting information (Figure 6).

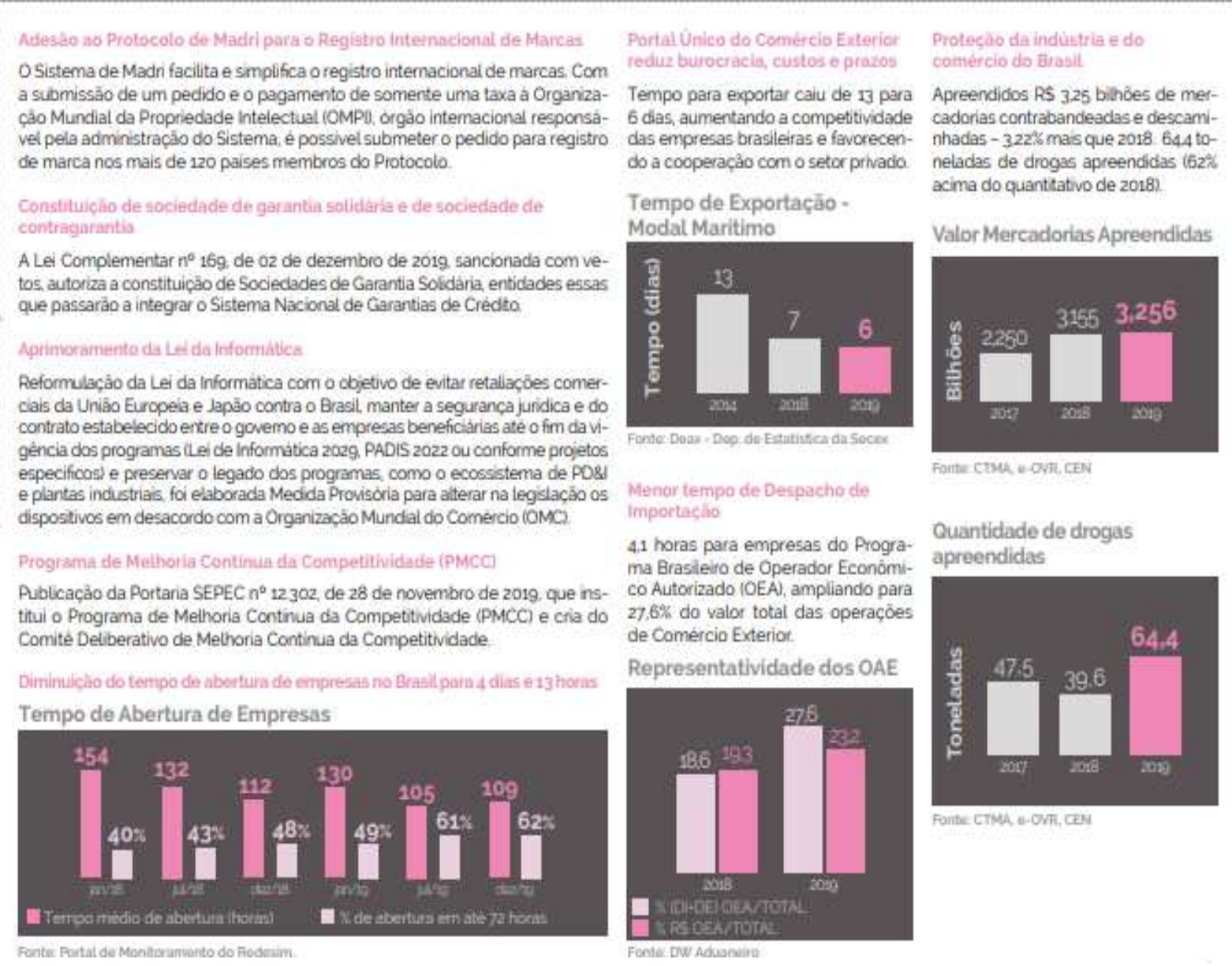

Figure 6 - Integrated Management Report of the Ministry of Economy. 2019

Source: Ministério da Economia (2019)

Despite the fact that the 2019 report presented a great evolution compared to the versions presented in previous years, bringing a broader Relevant Content with a Focus on the Citizens, and keeping the characteristics of Visually Appealing, Distribution of the Report and Accordance with Generally Accepted Accounting Principles, the Integrated Management Report of the Ministry of Economy suffers from the same problems already mentioned in the State of Bahia Annual Simplified Accountability Report, since it is still a technical document in terms of language.

The chapter dealing with budgetary, financial and accounting information is still difficult to understand for those who do not have a financial or accounting background (Figure 7). As can be seen, the difficulty in showing accounting and financial information in an understandable language seems to be a recurrent factor in the official reports of the Brazilian governments. This phenomenon had already been captured by Cabral and Aquino (2020), who, when analyzing eye movement and cognitive challenges for understanding PFRs, concluded that the main challenge for understanding PFRs is the presence of technical accounting terms. 


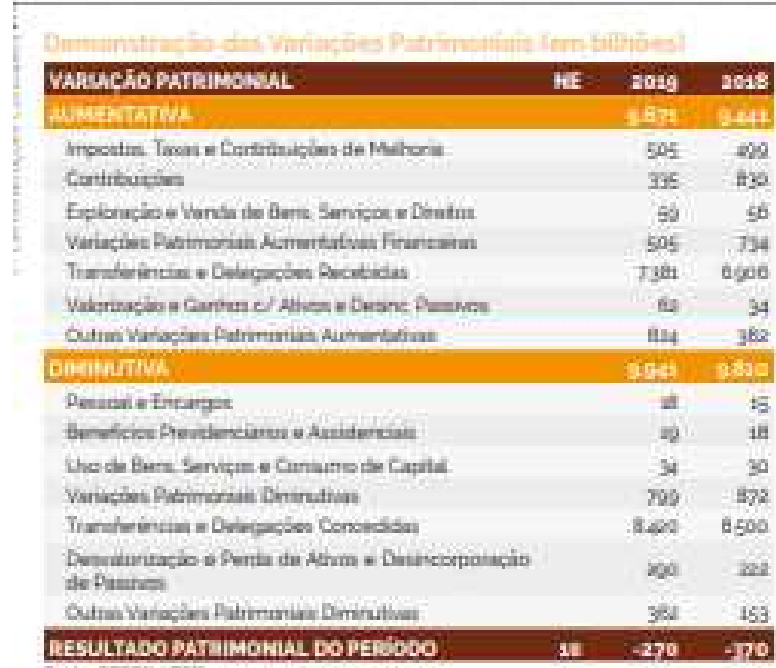

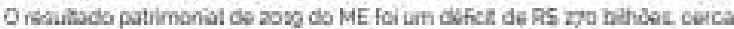

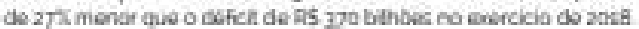

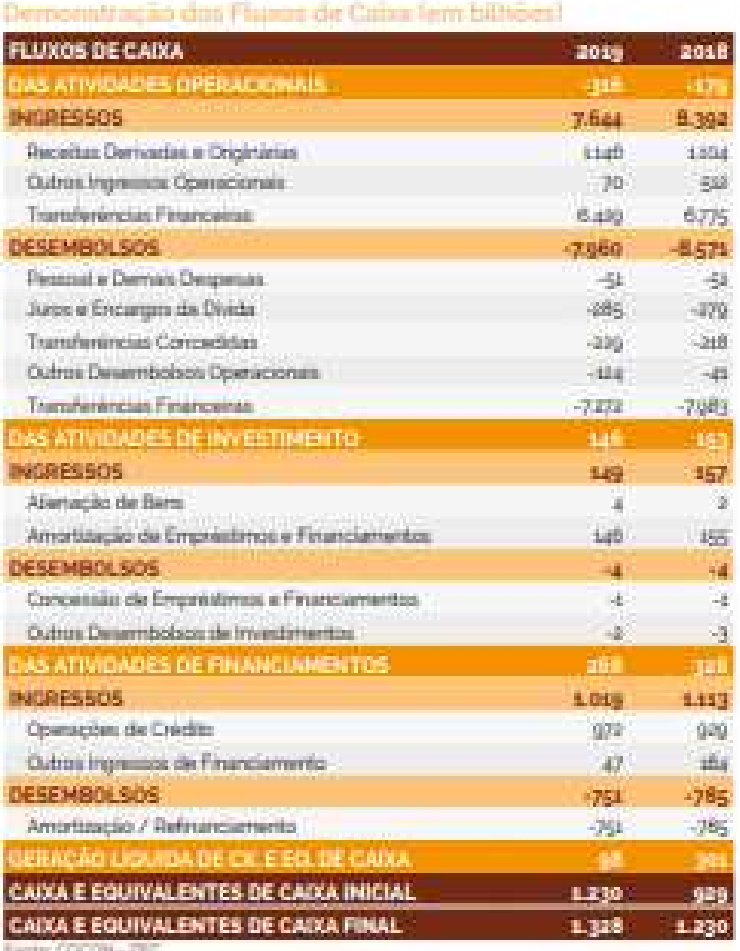

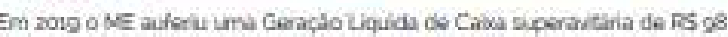

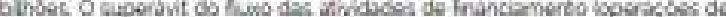

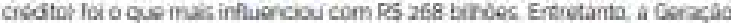

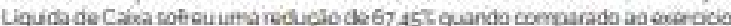

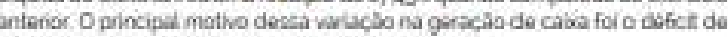

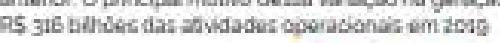

Figure 7 - Management Report. 2019, chapter on budget, financial and accounting information Source: Ministério da Fazenda (2019)

The TCU's portal pointed out that the previous reports usually contained between 1800 to 3000 pages, whereas the initiative totalized only 152 pages, therefore, much more concise. It is, however, important to highlight that a 152 pages report is still a very extensive report when comparing to reports from other countries. Also, the reading is considerably tiring and contains many technical terms difficult to understand. It is a great initiative and has evolved well over the years to a more accessible language, but it still has many improvements to be made.

\subsection{Open Government Partnership}

An Open Government Partnership (OPG) was launched in 2011 with the aim of spreading and encouraging, globally, government practices related to government transparency, access to public information and social participation, and currently has 75 countries worldwide (OGP, 2011; Bertin et al., 2019).

Brazil is one of OGP's co-founders, along with Indonesia, Mexico, Norway, the Philippines, South Africa, the United Kingdom and the United State. The General Controller (Controladoria Geral da União) was the entity responsible for leading the insertion of Brazil into the OGP, articulating with various public agencies and civil society to build the Brazilian Action Plans.

In the methodology developed in 2018, the national action plan was divided into three stages: (i) selection of themes to be worked on in the action plan; (ii) construction of national action plans in open government through co-creation workshops; and (iii) approval of the action plan by the company. The strongest aspects of OPG are related to the fact that it brings Basic Information, Easily Understandable and Focus on the Citizens, which are the main characteristics pointed out in the literature when it comes to PRF. However, Brazil still has a lot to evolve: the size and population imposes obvious challenges implementing and disseminating a unified model through all the twenty-seven states and more the five thousand municipalities.

In addition, risks related to political-institutional changes and possible discontinuities of partnerships for the execution of the milestones were identified; low availability or lack of prioritization by those responsible for the milestones at partner institutions; and lack of orchestration of Open Science-related initiatives in the absence of a legal framework and formally established guidelines (Bertin et al., 2019). 


\subsection{Citizen's Accounting Statement}

Inspired by the Law 12,527/2011, which regulated access to information in Brazil (also known as the access to information law - LAI), in 2016 it was proposed to create the Citizen's Accounting Statement (DCC) for implementation and presentation by Brazilian municipalities. In November 2020 the project was presented to the city council of Novo Hamburgo in the state of Rio Grande do Sul, with the proposition that the DCC be adopted for the presentation of the income and expenses of that municipality (Figure 8).

Unlike the other Brazilian experiences analyzed, the focus of the DCC is restricted to budgetary, financial and accounting information, which limits its evaluation in the light of the characteristics presented in the conceptual model, but it can serve as an experience due to the format presented.

\begin{tabular}{|c|c|c|c|c|c|c|c|}
\hline DESPESISPREFIIURA - DGG & 010 & 12019 A 3112 & 2019 & & \multirow{3}{*}{$\begin{array}{l}\text { SOBRE } \\
\text { EMPENHO } \\
\end{array}$} & \multirow{3}{*}{$\begin{array}{c}\text { SORRE } \\
\text { UQUUDACAOAO }\end{array}$} & \multirow{3}{*}{$\begin{array}{c}\text { SOBRE } \\
\text { WMGAMENTOS }\end{array}$} \\
\hline 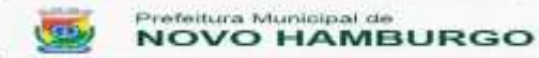 & \multicolumn{4}{|c|}{ DCC-DEMONSTRATIVO CONTÁBIL DO CIDADĀO } & & & \\
\hline 2019 & 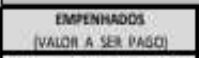 & 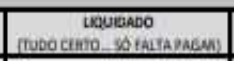 & \multicolumn{2}{|r|}{ PAGO } & & & \\
\hline 3.1.0.0.0.00.60.00.00.00 DESPESAS COM FOLHA DE PAGAMENTO & $269.592 .851,22$ & $269.579 .331,90$ & RS & $241,699,376,13$ & $33,97 \%$ & $34,93 \%$ & $34,31 \%$ \\
\hline DESPESAS COM FOLHA DE PAGAMENTO . CONCURSADOS & & & & & $0,00 \%$ & $0,00 \%$ & $0,00 \%$ \\
\hline DESPESAS COM FOLHA DE PAGAMEVTO - CARGOS DE CONFIAASCA & & & & & $0,00 \%$ & $0,00 \%$ & $0,00 \%$ \\
\hline JUROS E ENCARGOS DA DIVIDA & $11.952 .232,68$ & $11.952 .232,68$ & ASS & $11.952 .232,68$ & $1,51 \%$ & $1,55 \%$ & $1,70 \%$ \\
\hline 329.021 .010 .000 .000 lunos da dvida contratada com institienoes financeiras & $2.321 .053,55$ & $2321,053,55$ & RS & $2.321053,55$ & $0,29 \%$ & $0,30 \%$ & $0,33 \%$ \\
\hline 329.021030000 .000 funcer da divida contratada ne exteriox & $1702.590,61$ & $17202.569,51$ & RS & $1.702 .569,61$ & $0,21 \%$ & $0,22 \%$ & $0,24 \%$ \\
\hline 329.021 .990 .000 .000 Outros juros da divida coetratada & $2: 180,483,75$ & $2.180 .693,75$ & AS & $2.180 .493,75$ & $0,27 \%$ & $0,28 \%$ & $0,31 \%$ \\
\hline $329.02010 .100,000$ Encargos da Divida Contratada no Exteris & $249.456,25$ & $299.466,25$ & RS & $206,466,25$ & $0,03 \%$ & $0,03 \%$ & $0,04 \%$ \\
\hline 329. $121990,000,000$ Dutros juros da enda contratada - INTRA & $5,498.649,52$ & $5,498.649,52$ & BSS & $5,498.649,52$ & $0,69 \%$ & $0,71 \%$ & $0,78 \%$ \\
\hline
\end{tabular}

Figure 8 - Citizen's accounting statement

Source: available on the portal of the city of Novo Hamburgo/RS (2019). https://dcc.cnt.br/wpcontent/uploads/2020/04/2019-DCC-PREFEITURA-NH-.pdf

Although it is also a great initiative because it is in fact a simplified report (with only six pages), the DCC is nothing more than a technical document in terms of language, difficult to understand for those without financial or accounting training, only reduced to a few pages. It is observed that the model has also not evolved over the years, practically reproducing in 2020 the same information already listed in 2016 and in the following years, presented in the same way.

\section{Concluding Remarks}

Citizens have a crucial role in government decision-making process, and the decreasing trust on Governments is an important awakening justifying investment in solutions to approximate citizens and administrators. In this scenario, the PFR comes to light as an important resource to improve citizen's understanding of State`s finances and condition.

With the purpose of developing a conceptual model that can be used by Governmental Entities and can fulfil expectations from both government and citizens, we combined the concepts and characteristics presented in the literature with the most recurrent eligibility requirements found in seven awards/certificates, resulting in nine relevant characteristics: basic information, easily understandable, audited information, feedback statements, accordance with generally accepted accounting principles, visually appealing, distribution of the report, relevant content and focus on the citizens.

When applying the results obtained to the PFR elaboration experiences developed in Brazil, it was found that there is already an evolution when adopting a more attractive look and a wider dissemination, however, the reports are still long compared to international experiences and still the content and technical language of official reports predominate, which are difficult for Brazilian citizens who do not have financial or accounting training.

Being simple, the proposed model can be considered an incentive to governments with incipient practice in publishing PFRs. The next step is to gather more information on how this model would be effectively applied in practice. It may be difficult to implement it because of the numerous variables that can vary according to each government.

As for research limitations, the selection of the awards/certificates was random due to the difficulty of finding them. The theme is also very new and has not been properly disseminated to other countries besides the United States and Canada yet. Therefore, the number of studies is low and centered in few researchers.

As the interest on this subject is rising, it is essential to continue disseminating the idea, influencing current researchers and promoting this extremely relevant theme which can improve the quality of the government-citizen relationship. 


\section{References}

Allison, G. S. (1995). GFOA's Popular Reporting Awards Program: Revised and Improved. Government Finance Review, 11(3), 36-37.

Association of Government Accountants. Citizen-Centric Reporting (CCR). Retrieved from https://www.agacgfm.org/Standards-Guidance/CCR.aspx

Association of Government Accountants. Who is AGA? Retrieved from https://www.agacgfm.org/Membership/Learn-About-AGA/Who-is-AGA.aspx

Association of School Business Officials International. Certificate of Excellence in Financial Reporting. Retrieved from https://asbointl.org/awards-career-development/certificate-of-excellence-in-financial-reporting

Bertin, P. R. B., Fortaleza, J. M., Silva, A. C., \& Okawachi, M. F. (2019). A Parceria para Governo Aberto como plataforma para o avanço da Ciência Aberta no Brasil. Transinformação, v.31, e190020, http://dx.doi.org/10.1590/2318-0889201931e190020

Biancone, P., Secinaro, S., \& Brescia, V. (2016a). Popular report and Consolidated Financial Statements in public utilities. Different tools to inform the citizens, a long journey of the transparency. International Journal of Business and Social Science, 7(1), 111-124.

Biancone, P., Secinaro, S., \& Brescia, V. (2016b). The Popular Financial Reporting: Focus on Stakeholders-The first European Experience. International Journal of Business and Management, 11(11), 115-125. DOI: https://doi.org/10.5539/ijbm.v11n11p115

Biancone, P. P., Secinaro, S., \& Brescia, V. (2017). Popular financial reporting: Results, expense and welfare markers. African Journal of Business Management, 11(18), 491-501.

https://doi.org/10.5897/AJBM2017.8367

Biancone, P., Secinaro, S. F., Brescia, V., \& lannaci, D. (2019). The Popular Financial Reporting between Theory and Evidence. International Business Research, 12(7). DOI: https://doi.org/10.5539/ibr.v12n7p45

Biancone, P. P., Secinaro, S., \& Brescia, V. (2020). Popular Financial Reporting: A New Information Tool for Local Public Groups. In Financial Determinants in Local Re-Election Rates: Emerging Research and Opportunities (pp. 129-175). IGI Global. DOI: https://doi.org/10.4018/978-1-5225-7820-8.ch006

Brusca, I., \& Montesinos, V. (2006). Are citizens significant users of government financial information?. Public Money and Management, 26(4), 205-209. DOI: https://doi.org/10.1111/i.14679302.2006.00526.x

Cabral, L.M, \& Aquino, A. C. B. (2020). Movimento ocular e desafios cognitivos na compreensão de Relatórios Populares. XX USP International Conference in Accounting.

Carpenter, F.H., Sharp, F.C. (1992). Popular reporting: local government financial reports to the citizenry. Governmental Accounting Standards Board, Norwalk.

CGU Controladoria Geral da União. Parceria para Governo Aberto. Retrieved from http://governoaberto.cgu.gov.br/

Clay, P. M., \& Olson, J. (2008). Defining" fishing communities": vulnerability and the Magnuson-Stevens fishery conservation and management act. Human Ecology Review, 143-160.

Clay, J. A. (2010). Appendix H: Recent collaboration practice literature. Strategic Collaboration in Public and Nonprofit Administration: A Practice-Based Approach to Solving Shared Problems, 343. https://doi.org/10.1201/9781420088762-a8

Cohen, S., \& Karatzimas, S. (2015). Tracing the future of reporting in the public sector: introducing integrated popular reporting. International Journal of Public Sector Management. https://doi.org/10.1108/IJPSM-11$\underline{2014-0140}$

Cohen, S., Mamakou, X. J., \& Karatzimas, S. (2017). IT-enhanced popular reports: Analyzing citizen preferences. Government information quarterly, 34(2), 283-295. https://doi.org/10.1016/i.giq.2017.04.003 
GASB Government Accounting Standards Board. About the Gasb. Retrieved from https://www.gasb.org/jsp/GASB/Page/GASBSectionPage\&cid=1176168081485

GFOA Government Finance Officers Association About GFOA. Retrieved from Government Finance Officers Association: http://www.gfoa.org/about-gfoa

GFOA Government Finance Officers Association. Canadian Award for Financial Reporting Program (CAnFR Program). Retrieved from http://www.gfoa.org/canfr

GFOA Government Finance Officers Association. Certificate of Achievement for Excellence in Financial Reporting from http://www.gfoa.org/certificate-achievement-excellence-financial-reporting-cafr-program

GFOA Government Finance Officers Association. Popular Annual Financial Reporting Award Program (PAFR Program). Retrieved from http://www.gfoa.org/pafr

Groff, J. E., Pitman, M. K., \& Tervo, W. (2017). Why don't municipal governments produce popular annual financial reports? A preliminary study with evidence from Texas. International Journal on Governmental Financial Management, 27(2), 65-84.

Hermann, K. R. (2011). Creating an excellent popular financial report. Government Finance Review, 27(5), 41-44.

IPSASB (2014). The conceptual framework for general purpose financial reporting by public sector entities. Handbook of international public sector accounting pronouncements, 1.

Irvin, R. A., \& Stansbury, J. (2004). Citizen participation in decision making: is it worth the effort?. Public administration review, 64(1), 55-65. https://doi.org/10.1111/.1540-6210.2004.00346.x

Jordan, M., Yusuf, J. E., Mayer, M., \& Mahar, K. (2016). What citizens want to know about their government's finances: Closing the information gap. The Social Science Journal, 53(3), 301-308. https://doi.org/10.1016/j.soscij.2016.04.007

Jordan, M. M., Yusuf, J. E., Berman, M., \& Gilchrist, C. (2017). Popular financial reports as fiscal transparency mechanisms: An assessment using the fiscal transparency index for the Citizen User. International Journal of Public Administration, 40(8), 625-636.

https://doi.org/10.1080/01900692.2016.1186175

Kopits, G., Craig, J. D., \& Kopits, G. (1998). Transparency in government operations (Vol. 158). Washington, DC: International monetary fund. https://doi.org/10.5089/9781557756978.084

Lee, M. (2006). The history of municipal public reporting. Intl Journal of Public Administration, 29(4-6), 453476. https://doi.org/10.1080/01900690500436982

Manes-Rossi, F. (2019). New development: Alternative reporting formats: a panacea for accountability dilemmas?. Public Money \& Management, 39(7), 528-531. https://doi.org/10.1080/09540962.2019.1578540

Ministério da Economia. (2020) Relatório de Gestão Integrado do Ministério da Economia. Retrived from https://www.gov.br/economia/pt-br/centrais-de-conteudo/publicacoes/relatorios/arquivos/2020/rgi-2019 2906-2020.pdf/view

Monteiro, R. (2016). Transparência Bahia publica prestação de Contas Simplificada do Estado. Retrieved from http://www.politicalivre.com.br/2016/09/transparencia-bahia-publica-prestacao-de-contas-simplificadado-estado/

OECD. Government at a Glance 2017, OECD Publishing. Retrieved from:

http://dx.doi.org/10.1787/gov glance-2017-en

Office of Financial Management. Comprehensive Annual Financial Report. Retrieved from https://www.ofm.wa.gov/accounting/financial-audit-reports/comprehensive-annual-financial-report

Oliveira, J. H. C. (2013). Neuromarketing, tomada de decisão e consumo sustentável entre jovens: um estudo sobre o processamento cognitivo duplo e seu impacto na brand equity por meio da neurociência 
visual (Doctoral dissertation, Tese de Livre-Docência em Administração-Faculdade de Economia, Administração e Contabildiade de Ribeirão Preto, Universidade de São Paulo).

OPGOpen Government Partnership. Brazil. Retrieved from https://www.opengovpartnership.org/countries/brazil

Public Finance Awards. Achievement in Financial Reporting \& Accountability. Retrieved from https://www.publicfinanceawards.co.uk/categories/

Secretaria da Fazenda do Estado da Bahia. (2019). Prestação de Contas Anual Simplificada de 2019. Salvador, Bahia. Retrieved from http://www.transparencia.ba.gov.br/Home/ObterDocumentoHome/PrestacaoContasAnualSimplificada2018

Sharp, F. C., Carpenter, F. H., \& Sharp, R. F. (1998). Popular financial reports for citizens. The CPA Journal, 68(3), 34.

Silva, V. R., \& de Medeiros, M. R. A. (2020). Desafios e possibilidades para o controle social de políticas públicas no atual contexto de retrocesso dos direitos sociais. Textos \& Contextos (Porto Alegre), 19(1), e36745-e36745. DOI: https://doi.org/10.15448/1677-9509.2020.1.36745

TCU Tribunal de Contas da União. Ministério da Fazenda segue TCU e faz relatório de gestão acessível ao cidadão. Retrieved from https://portal.tcu.gov.br/imprensa/noticias/ministerio-da-fazenda-segue-tcu-e-fazrelatorio-de-gestao-acessivel-ao-cidadao.htm

TCU Tribunal de Contas do Estado da Bahia. Sefaz apresenta ao TCE/BA a Prestação de Contas Anual Simplificada / 2015. Retrieved from https://www.tce.ba.gov.br/noticias/sefaz-apresenta-ao-tce-ba-aprestacao-de-contas-anual-simplificada-2015

Yusuf, J. E. W., \& Jordan, M. M. (2012). Effective popular financial reports: The citizen perspective. Journal of Government Financial Management, 61(4).

Yusuf, J. E., Jordan, M. M., Neill, K. A., \& Hackbart, M. (2013). For the people: Popular financial reporting practices of local governments. Public Budgeting \& Finance, 33(1), 95-113. https://doi.org/10.1111/j.1540$\underline{5850.2013 .12003 . x}$

Yusuf, J. E., \& Jordan, M. M. (2015). Popular financial reports: Tools for transparency, accountability and citizen engagement. The Journal of Government Financial Management, 64(1).

\section{NOTES}

\section{ACKNOWLEDGMENT}

We thank the team of the Brazilian Agency for The Promotion of Exports and Investments (Apex-Brasil), which allowed during the year 2018 the theme to be discussed and receive contributions from the agency's professionals, in particular the person of Mr. Francisco de Assis Leme Franco.

\section{AUTHORSHIP CONTRIBUTION}

Conception and elaboration of the manuscript: D.V. Lima, F. V. S. P. Martins

Data collection: D.V. Lima, F. V. S. P. Martins

Data analysis: D.V. Lima, F. V. S. P. Martins

Discussion of results: D.V. Lima, F. V. S. P. Martins

Review and approval: D.V. Lima, F. V. S. P.

\section{DATASET}

The entire data set that supports the results of this study was published in the article itself.

\section{FINANCING}

Does not apply.

\section{CONSENT TO USE IMAGE}

Does not apply.

\section{APPROVAL OF THE RESEARCH ETHICS COMMITTEE}

Does not apply. 


\section{CONFLICT OF INTERESTS}

Does not apply.

\section{USE LICENSE}

Copyrights for articles published in this journal are the author's, with first publication rights for the journal. Due to appearing in this Public Access Magazine, the articles are free to use, with their own attributions, in educational, professional and public management applications. The magazine adopted the Creative Commons Attribution 4.0 International license - CC BY NC ND. This license allows accessing, downloading (downloading), copying, printing, sharing, reusing and distributing the articles provided that the source is acknowledged, attributing the due authorship credits. In such cases, no permission is required from the authors or editors. Authors are authorized to assume additional contracts separately, for non-exclusive distribution of the version of the work published in this journal (eg, publishing in institutional repository or a book chapter).

\section{PUBLISHER}

Federal University of Santa Catarina. Accounting Sciences Course and Postgraduate Program in Accounting. Publication on the UFSC Journal Portal. The ideas expressed in this article are the responsibility of their authors, and do not necessarily represent the opinion of the editors or the university.

\section{EDITORS}

Carlos Eduardo Facin Lavarda and Suliani Rover

\section{HISTORIC}

Received on: 30/07/2020 - Peer reviewed on: 16/11/2020 - Reformulated on: 08/02/2021 - Recommended for publication on: 09/02/2021 - Published on: 22/03/2021 